\title{
Protease Activity and Gel-forming Ability of Ginger Rhizome Juice
}

\author{
Norihiro Yamada ${ }^{1}$, Yasushi Kokean ${ }^{2}$, Kaori Umetani ${ }^{2}$, Jun Shimizu ${ }^{3}$, Osamu Kurita ${ }^{2} \&$ Kazunobu Tsumura ${ }^{4}$ \\ ${ }^{1}$ Tsu City College, Mie, Japan \\ ${ }^{2}$ Mie Prefecture Industrial Research Institute, Mie, Japan \\ ${ }^{3}$ Josai University, Saitama, Japan \\ ${ }^{4}$ FUJI OIL HOLDINGS INC., Osaka, Japan \\ Correspondence: Kazunobu Tsumura, Research Institute for Creating the Future, FUJI OIL HOLDINGS INC., 1 \\ Sumiyoshi-cho, Izumisano-shi, Osaka 598-8540, Japan. Tel: 81-72-463-1751. \\ E-mail: tsumura.kazunobu@ @o.fujioil.co.jp
}

Received: February 5, 2020

Accepted: February 27, $2020 \quad$ Online Published: March 5, 2020

doi:10.5539/jfr.v9n2p30

URL: https://doi.org/10.5539/jfr.v9n2p30

\begin{abstract}
The ginger rhizome has been known to contain proteolytic enzymes. In this study, we evaluated the protease activities in juice extracted from ginger rhizomes. The specific protease activity in juice from ginger ripened after harvesting was higher than that of ginger that was not ripened after harvesting. Sodium dodecyl sulphate-polyacrylamide gel electrophoresis indicated that the ginger rhizome juice displaying high specific protease activity contained a $30 \mathrm{kDa}$ protein. This juice was also observed to have milk gel-forming ability.
\end{abstract}

Keywords: ginger rhizome juice, protease, gel-forming ability

\section{Introduction}

Ginger rhizomes have been used worldwide as a spice or condiment for over 2,000 years (Moghaddasi \& Kashani, 2012) as well as for medicinal purposes (Kikuzaki, 2000; Butt \& Sultan, 2011; Bhatt et al., 2013; Kimura, Pancho \& Tsuneki, 2016). In Japan, ginger is called "Syoga," and ginger rhizomes are classified depending on their post-harvest ripening state. Ginger rhizomes ripened for over two months after harvest are called "Hine-Syoga," and those used immediately after harvest are called "Sin-Syoga."

There are several reports on ginger rhizome proteases (Thompson, Wolf \& Allen, 1973; Ohtsuki et al., 1995; Choi \& Laursen, 2000; Adulyatham \& Owusu-Apenten, 2005; Su, Huang \& Wang, 2009; Hashim et al., 2011; Huang et al., 2011; Nishiyama, \& Araki, 2018). Many researchers have also indicated that the ginger protease has a molecular weight of about $30 \mathrm{kDa}$ (Ohtsuki et al., 1995; Adulyatham \& Owusu-Apenten, 2005; Hashim et al., 2011; Huang et al., 2011). In addition, this ginger protease is a monomer in solution, as determined by gel filtration chromatography (Ichikawa, Sasa \& Michi, 1973; Ohtsuki et al., 1995).

Ginger milk pudding, termed as jiang zhi Zhuang nai, is a traditional Chinese dessert (Nishimura \& Goto, 2010). The main principle of preparing the pudding is based on the ability of the ginger protease to decompose the casein in milk; the milk coagulation activity of ginger juice has been reported (Hashim et al., 2011; Huang et al., 2011). However, preparation of ginger milk pudding sometimes fails even when performed in the same manner as previous successful attempts. We speculate that this might be due to differences in the type of milk and/or ginger. The effects of the type of milk on preparation of ginger milk pudding have been investigated previously, and it was found that the state of the pudding varied according to the type of milk used (Yamada, 2015). However, the effects of differences in the type of ginger are unknown.

In this study, we investigated the differences in the specific protease activity of various ginger rhizomes and the gel-forming ability of ginger milk.

\section{Materials and Methods}

\subsection{Materials}

The ginger rhizomes were purchased from a local market in Tsu-shi, Mie, Japan, and from the Shimizu Products Corp. (Chiba, Japan) by mail order. All chemicals and reagents employed were of analytical grade. 


\subsection{Preparation of Ginger Juice}

Twelve ginger rhizome samples with different varieties and ripening states were used (Table 1). The ginger rhizomes were washed and cut into fine pieces, and the juice was squeezed using a slow juicer (HEALSIO Juicepresso, Sharp Corp., Osaka, Japan). Each juice sample was centrifuged at 2,150 $\times \mathrm{g}$ for $20 \mathrm{~min}$ at $4{ }^{\circ} \mathrm{C}$ (LX-120, TOMY SEIKO Co, Ltd., Tokyo, Japan), and the supernatants were filtered using a filter paper (No. 5C, ADVANTEC MFS, Inc., California, USA). To stabilize the enzymes, $0.2 \%$ L-ascorbic acid and $10 \mathrm{mM}$ L-cysteine hydrochloride were added (Adulyatham \& Owusu-Apenten, 2005; Nafi et al., 2013). The prepared ginger rhizome juices were stored at $-80^{\circ} \mathrm{C}$ until further use.

\subsection{Evaluation of Specific Protease Activity in Ginger Rhizome Juice}

The protein concentrations in the ginger rhizome juices were determined using a Pierce ${ }^{\mathrm{TM}}$ BCA Protein Assay Kit (Thermo Fisher Scientific Inc., Waltham, Massachusetts, USA).

Protease activity was measured by the following method. The substrate solution was prepared by dissolving $1 \%$ $(\mathrm{w} / \mathrm{v})$ of casein in $0.1 \mathrm{M}$ potassium phosphate buffer, $\mathrm{pH}$ 7.0. The assay was performed by incubating $500 \mu \mathrm{L}$ of the substrate (casein) solution with $10 \mu \mathrm{L}$ of the ginger rhizome juice, and the mixture was incubated at $60{ }^{\circ} \mathrm{C}$ for $30 \mathrm{~min}$; the enzymatic reaction was terminated by addition of $500 \mu \mathrm{L}$ of $0.4 \mathrm{M}$ trichloroacetic acid (TCA) to the mixture. A blank sample was prepared by adding TCA solution to the substrate solution before addition of the ginger juice. After $30 \mathrm{~min}$ of incubation at room temperature, the precipitated protein was removed by centrifugation at $20,000 \times \mathrm{g}$ for $15 \mathrm{~min}$, and the degraded protein in the supernatants was evaluated based on an increase in the spectrophotometric absorbance at $280 \mathrm{~nm}$ (GeneQuant 1300, GE Healthcare, Illinois, USA). Under the above conditions, the concentration of the protease required to raise the absorbance value to 1.00 was defined as one unit. Then, the protease activity per protein mass $(\mathrm{mg})$ in the ginger rhizome juice was defined as the specific protease activity (Units/mg).

\subsection{Electrophoresis}

Sodium dodecyl sulphate-polyacrylamide gel electrophoresis (SDS-PAGE) was carried out using a reagent kit based on the Laemmli method (Cosmo Bio Co., Ltd., Tokyo, Japan). The samples were reduced by adding a solution of $10 \% 2$-mercaptoethanol. The ginger rhizome juice samples were mixed with $4.3 \%$ SDS at a ratio of $1: 1$ and heated at $100{ }^{\circ} \mathrm{C}$ for 5 minutes and $10 \mu \mathrm{L}$ was applied to the gel. The concentration of the gel was $12.5 \%$ acrylamide and the electrophoresis was conducted at a constant current of $30 \mathrm{~mA}$ for $60 \mathrm{~min}$. Proteins were stained with Coomassie brilliant blue R-250 (PAGE Blue 83, Cosmo Bio Co., Ltd., Tokyo, Japan). The protein molecular weight marker kit, SIMASIMA Unstained Low Range Protein Ladder (Cosmo Bio Co., Ltd., Tokyo, Japan), was used to identify the molecular weight of the protein.

\subsection{Evaluation of gel-forming ability of ginger milk}

Gels were prepared by incubating the mixture of $50 \mathrm{~mL}$ milk (Jersey Milk Premium 5.0, Hiruzen Dairy Agricultural Cooperatives, Okayama, Japan) and $1.5 \mathrm{~mL}$ of ginger rhizome juice in a cylindrical container (48 $\mathrm{mm}$ diameter) at $60{ }^{\circ} \mathrm{C}$ for $60 \mathrm{~min}$. The gel strength was measured using a creep meter (RHEONER, RE2-33005S, Yamaden Co., Tokyo, Japan) with a $20 \mathrm{~N}$ load cell. The gels were compressed with a cylindrical plunger (diameter $16 \mathrm{~mm}$ ) at $1 \mathrm{~mm} / \mathrm{sec}$, and the clearance was $50 \%$ of the gel height. The gel was compressed twice and analyzed. The hardness value was determined as the peak force during the first compression. Adhesiveness was determined from the negative force area after first compression. Cohesiveness was determined as the ratio of the second compression area to the first compression area.

\subsection{Statistical Analysis}

The experiments were performed in triplicates and the data are presented as mean \pm standard deviation. Significant differences between each sample were analyzed using Welch's t-test, and p-values of $<0.05$ were considered statistically significant. 
Table 1. Specific protease activity of ginger rhizome juices

\begin{tabular}{llll}
\hline Sample No. & Variety name* & Ripening state** & Specific protease activity (Unit/mg) \\
\hline 1 & OGON KOKUZO II & H & 0.017 \\
2 & YANAGIKOGANE & H & 0.452 \\
3 & YANAGIKOGANE & H & 0.262 \\
4 & Unknown & H & 0.110 \\
5 & TOSATAICHI & H & 0.080 \\
6 & Unknown & H & 0.121 \\
7 & Unknown & H & 0.308 \\
8 & TOSATAICHI & H & 0.070 \\
9 & Unknown & H & 0.275 \\
10 & Unknown & H & 0.403 \\
11 & Unknown & S & 0.037 \\
12 & Unknown & S & 0.030 \\
\hline
\end{tabular}

* Registered variety by the Ministry of Agriculture, Forestry and Fisheries of Japan.

** H: Hine-Syoga (used after ripening for 2 months after harvesting),

S: Sin-Syoga (used immediately after harvesting).

\section{Results and Discussion}

\subsection{Specific Protease Activity of Ginger Rhizome Juices}

The protein concentration and protease activity in various ginger rhizome juice samples were determined as shown in Table 1. Higher specific protease activity was observed for five kinds of Hine-Syoga samples (No. 2, 3, 7,9 , and 10). In contrast, very low specific protease activity was observed in the Sin-Syoga samples (No. 11 and 12). From the viewpoint of variety, sample No.1 (OGON KOKUZO II variety) had very low specific protease activity compared to other varieties. Samples No.5 and 8 were of the same variety (TOSATAICHI) and showed relatively low specific protease activity, so it can be considered to be a variety with inherently low specific protease activity. Among the samples studied, the YANAGIKOGANE variety may have a higher specific protease activity. In contrast, OGON KOKUZO II and TOSATAICHI had lower specific protease activities. Regarding the rhizome samples ripened after harvesting, the rhizome juices of Sin-Syoga had lower protein concentrations and lower specific protease activities. Thus, the effect of ripening is an important issue that needs to be addressed; it is presently under study.

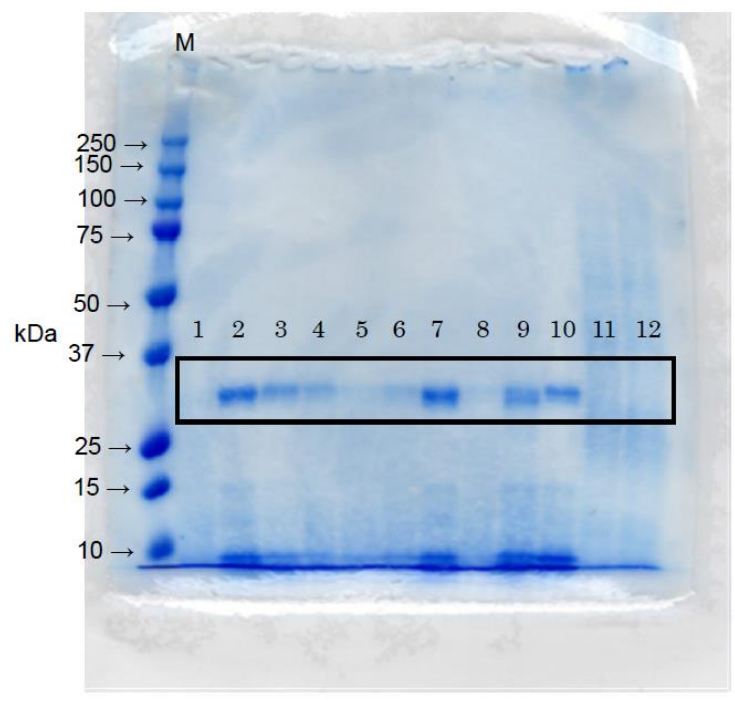

Figure 1. SDS-PAGE of ginger rhizome juices

Lane M: protein molecular weight markers.

Lanes 1-10: ginger rhizome juices of sample no.1-10 in Table 1.

The bands surrounded by a square are considered as a ginger protease. 


\subsection{Protein Profile of Ginger Rhizome Juice}

Figure 1 shows the protein profile of the ginger rhizome juices obtained by the SDS-PAGE. Samples No.2, 3, 7 , 9 , and 10, which had higher specific protease activity, depicted thick bands around $30 \mathrm{kDa}$, but the juice samples with lower specific protease activity (No.1, 5, 8, 11, and 12) showed almost no band. This result was consistent with that in previous reports that the ginger protease is a protein of about $30 \mathrm{kDa}$. From the results of the SDS-PAGE analysis, it may be possible to estimate the ranking of the specific protease activity in the ginger rhizome juices. However, it should also be taken into account that ginger protease activity differs depending on the source of the ginger, including its variety and the post-harvest ripening state.

\subsection{Gel-forming Ability of The Ginger Milk}

Ginger rhizome juice was used to examine the possibility of forming a milk gel. A ginger rhizome juice sample displaying a higher specific protease activity (No. 10 as a typical example) was selected for this experiment. The mechanism of the formation of the milk gel by ginger juice involves the aggregation of milk proteins by the ginger protease. The rheological result is shown in Figure 2. From the texture profile curve, properties of hardness, adhesiveness and cohesiveness were calculated to be $2.29 \pm 0.07\left[\times 10^{3} \mathrm{~N} / \mathrm{m}^{2}\right], 130 \pm 10\left[\mathrm{~J} / \mathrm{m}^{3}\right]$, and $0.327 \pm 0.231$, respectively. The results were similar to those obtained from a $2 \%(\mathrm{w} / \mathrm{w})$ gel of gelatin (Yamada, 2015). The ginger rhizome juice sample with a lower specific protease activity (No. 11 as a representative example) did not show any gel formation. This result strongly suggests that the ability to form a milk gel correlated with the extent of specific protease activity in the ginger rhizome juice. Although the physical properties of the milk gel are affected by the type of milk used, effect of the protease on the coagulation in ginger rhizome juice must also be considered. As a future perspective, it may be necessary to examine the clotting action of plant-based proteins such as soymilk (Yamada, Kokean, \& Tsumura 2019) in addition to cow milk.

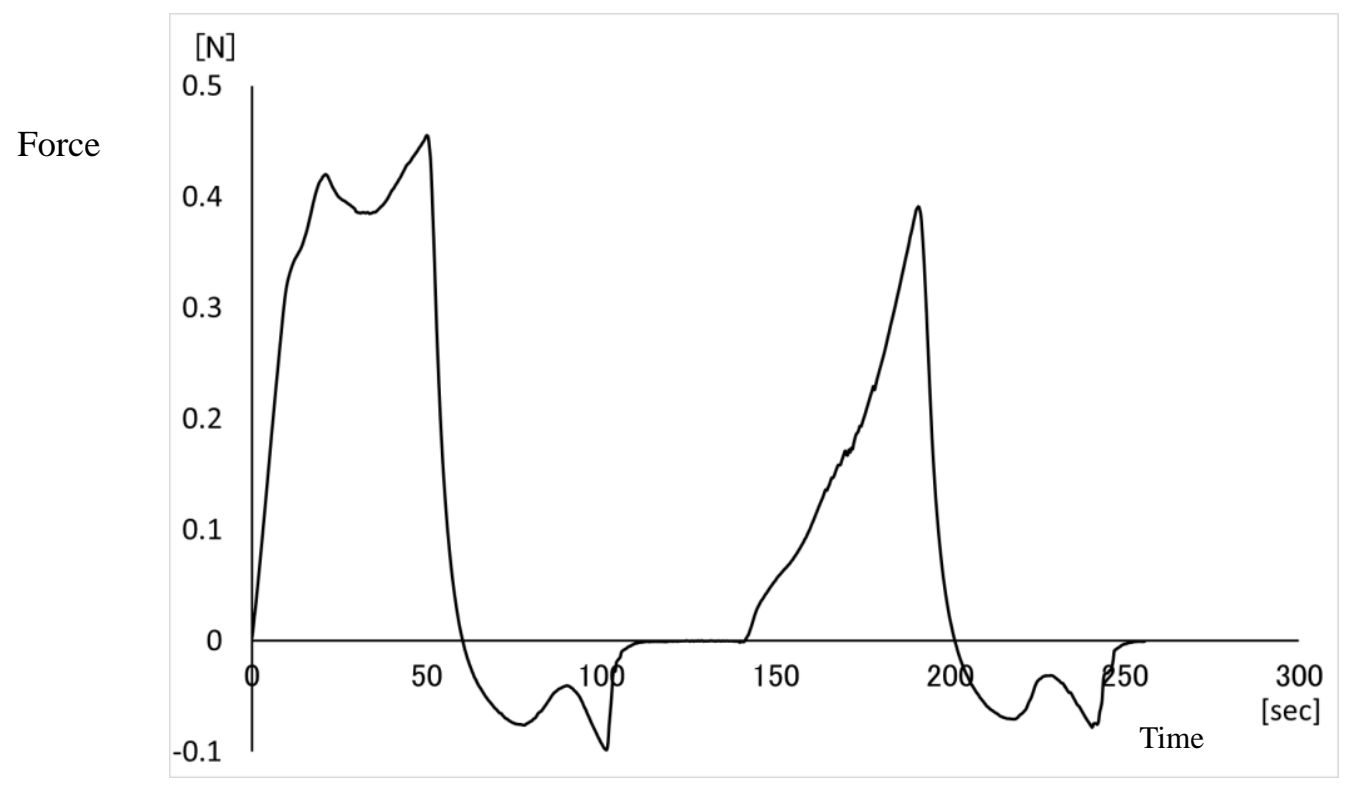

Figure 2. Texture profile curve of ginger milk gel

\section{Conclusion}

The results of this study demonstrate that the variety and the ripening state of ginger rhizomes affect their specific protease activity and ability to form a milk gel. Juices with high specific protease activity derived from ripened ginger had high gel-forming ability, and those of unripened ginger with low specific protease activity showed no gel-forming ability. These results provide insights into the industrial application of ginger proteases, for example, as clotting enzymes that can be used to prepare milk gels and different kinds of cheese.

\section{Acknowledgments}

This work was supported by the Okasan-Kato Foundation grant (17-1-50) and the Institute of Regional Stoles Tsu City College, Mie, Japan. We would like to thank Editage (www.editage.com) for English language editing. 


\section{References}

Adulyatham, P., \& Owusu-Apenten, R. (2005). Stabilization and partial purification of a protease from ginger rhizome (Zingiber offinale Roscoe). Journal of Food Science, 70(3), C231-C234. https://doi.org/10.1111/j.1365-2621.2005.tb07130.x

Bhatt, N., Waly, M. I., Essa, M. M., \& Ali, A. (2013). Ginger: A functional herb. In Food as Medicine. (pp. 51-72). Nova Science Publishers Inc., Hauppauge, NY, USA.

Butt, M. S., \& Sultan, M. T. (2011). Ginger and its health claims: molecular aspects. Critical reviews in food science and nutrition, 51(5), 383-393. https://doi.org/10.1080/10408391003624848

Choi, K. H., \& Laursen, R. A. (2000). Amino-acid sequence and glycan structures of cysteine proteases with proline specificity from ginger rhizome Zingiber officinale. European Journal of Biochemistry, 267(5), 1516-1526. https://doi.org/10.1046/j.1432-1327.2000.01152.x

Hashim, M. M., Mingsheng, D., Iqbal, M. F., \& Xiaohong, C. (2011). Ginger rhizome as a potential source of milk coagulating cysteine protease. Phytochemistry, 72(6), 458-464.

https://doi.org/10.1016/j.phytochem.2010.12.002

Huang, X. W., Chen, L. J., Luo, Y. B., Guo, H. Y., \& Ren, F. Z. (2011). Purification, characterization, and milk coagulating properties of ginger proteases. Journal of Dairy Science, 94(5), 2259-2269. https://doi.org/10.3168/jds.2010-4024

Ichikawa, Y., Sasa, H., \& Michi, K. (1973). Purification of ginger protease. Journal of Japan Society of Nutrition and Food Science, 26, 377-383. https://doi.org/10.4327/jsnfs1949.26.377

Kikuzaki, H. (2000). Ginger for drug and spice purposes. In Herbs, Botanicals and Teas as functional foods and nutraceuticals (pp.75-105). Technomic Publishing Co. Inc., Lancaster, PA, USA.

Kimura, I., Pancho, L. R., \& Tsuneki, H. (2016). Pharmacology of ginger. In Ginger (pp. 489-508). CRC Press, Boca Raton, FL, USA.

Moghaddasi, M. S., \& Kashani, H. H. (2012). Ginger (Zingiber officinale): A review. Journal of Medicinal Plants Research, 6(26), 4255-4258. https://doi.org/10.5897/JMPR11.787

Nafi, A., Foo, H. L., Jamilah, B., \& Ghazali, H. M. (2013). Properties of proteolytic enzyme from ginger (Zingiber officinale Roscoe). International Food Research Journal, 20(1), 363-368. Retrieved from http://www.ifrj.upm.edu.my/20\%20(01)\%202013/50\%20IFRJ\%2020\%20(01)\%202013\%20Hasanah\%20(1 35).pdf

Nishimura, K., \& Goto, M. (2010). Identification of the protease involved in and the effects of vitamin C on gel formation in ginger milk pudding (Jiang Zhi Zhuang Nai). Journal of Home Economics of Japan, 61(8), 463-471. https://doi.org/10.11428/jhej.61.463

Nishiyama, Y., \& Araki, T. (2018). Substrate Profiling of Cysteine Protease from Zingiber officinale. Food Biotechnology, 32(2), 148-161. https://doi.org/10.1080/08905436.2018.1455585

Ohtsuki, K., Taguchi, K., Sato, K., \& Kawabata, M. (1995). Purification of ginger proteases by DEAE-Sepharose and isoelectric focusing. Biochimica et Biophysica Acta, 1243(2), 181-184. https://doi.org/10.1016/0304-4165(94)00145-N

$\mathrm{Su}$, H. P., Huang, M. J., \& Wang, H. T. (2009). Characterization of ginger proteases and their potential as a rennin replacement. Journal of the Science of Food and Agriculture, 89(7), 1178-1185. https://doi.org/10.1002/jsfa.3572

Thompson, E. H., Wolf, I. D., \& Allen, C. E. (1973). Ginger rhizome: A new source of proteolytic enzyme. Journal of Food Science, 38(4), 652-655. https://doi.org/10.1111/j.1365-2621.1973.tb02836.x

Yamada, N. (2015). Effects of the source \& components of milk on the properties of milk gels prepared by the action of ginger juice. Journal for the Integrated Study of Dietary Habit, 26(2), 79-84. https://doi.org/10.2740/jisdh.26.79

Yamada, N., Kokean, Y., \& Tsumura, K. (2019). Novel insights into the formation of soymilk gel induced by ginger rhizome juice. Food Science and Technology Research, 25(5), 751-754.

https://doi.org/10.3136/fstr.25.751 


\section{Copyrights}

Copyright for this article is retained by the author(s), with first publication rights granted to the journal.

This is an open-access article distributed under the terms and conditions of the Creative Commons Attribution license (http://creativecommons.org/licenses/by/4.0/). 